\title{
IMPROVED BIOMASS AND BURNING EFFICIENCY FACTORS FOR FOREST FIRE EMISSIONS ESTIMATION IN CENTRAL CHILE
}

\author{
P. Oliva ${ }^{1 *}$, N. Medina ${ }^{1}$, L. Durán ${ }^{2}$, P. Vidal ${ }^{1}$ \\ ${ }^{1}$ Hémera Centro de Observación de la Tierra, Facultad de Ciencias, Universidad Mayor, Chile - (patricia.oliva, Natalia.medina, \\ paulina.vidal)@umayor.cl \\ ${ }^{2}$ Escuela de Ingeniería Forestal, Facultad de Ciencias, Universidad Mayor, Chile - leonardo.duran@umayor.cl
}

KEY WORDS: biomass burning, Sentinel-2, Chile, combustion, burn severity, schlerophyll forest

\begin{abstract}
:
In an era of increasing wildfires frequency and intensity an accurate estimation of the emissions released to the atmosphere is essential to reduce their impacts. In this study, we improve the accuracy of our estimations by introducing field measurements of biomass and adapting the burning efficiency factors to different levels of burn severity computed from Sentinel-2 data. The biomass measured in the field complemented the data found in the literature. The emissions derived were compared with the emissions from the GFED product showing a good agreement, although GFED values were higher than ours, suggesting that GFED may overestimate the emissions due to their coarse resolution and the generalized factors applied to large ecosystems.
\end{abstract}

\section{INTRODUCTION}

\subsection{General Instructions}

Wildfires across de globe are changing. Fires are more frequent and intense, due to weather and vegetation conditions, which made them harder to extinguish. The fire season is also longer every year, as it was observed in Australia and California in the last years. The current context of climate change is aggravating this situation as the vegetation is drier increasing their flammability (Yebra et al. 2018). On the other hand, there is an increasing interest on the air pollution and its effects on public health. Cases of extreme pollution arose in India, Indonesia and California in 2019 derived from different types of fire (agricultural, peat and forest fires, respectively).

Currently, there are some products at global scale that offer the estimation of the emissions released by biomass burning events, such as GFED (van der Werf et al. 2017), GFAS (Kaiser et al. 2012), or FINN (Wiedinmyer et al. 2011). These global products are provided at coarse resolution $\left(0.1-0.25^{\circ}\right)$ due to the limitations of their input data and the need for computational efficiency.

Methodologically, there are two bottom-up approaches to biomass burning emissions quantification. The first method follows the approach introduced by Seiler and Crutzen (1980), which describes the combustion process by combining burned area, available biomass, burning efficiency factor and emission factors. This approach is used in the emissions estimation performed in the GFED product (van der Werf et al. 2017). The second approach relates the energy released by the fire, through the use of the Fire Radiative Power (FRP), with the amount of dry matter combusted by the fire (Wooster et al. 2015). The GFAS product uses this second approach (Kaiser et al. 2012).

The global emission models commonly use generalized factors assign to large ecosystems, such as boreal or temporal forest, and fixed burning factors that do not account for a variable levels of biomass combustion. These characteristics introduce uncertainties and might produce overestimation of the derived emissions.

In 2017, 114 active fires burned throughout Chile at the same time on January 26th. These fires spread quickly due to the high temperatures, dry strong winds and low vegetation water content. The fire events burned more than 570,000 ha, from which $20 \%$ of the area was endangered native forest (CONAF, 2017).

The Mediterranean schlerophyll forests were the native forest ecosystem of central Chile $\left(30^{\circ}-35^{\circ} \mathrm{S}\right)$ most affected by the fires covering $15 \%$ of the total affected area. The Chilean native schlerophyll forests are composed of endemic evergreen tree species specifically adapted to drought conditions. The high concentration of endemism makes this ecosystem a biodiversity hotspot (Myers et al. 2000). The conservation of these forests is crucial to maintain their ecosystem functions, such as reducing air pollution, retaining water in soils, and modulating the climate (Dobbs, Kendal, y Nitschke 2014).

The National Forestry Corporation (CONAF) in Chile performed the estimation of the emissions produced by the fires, reporting a total of 78 million of Ton of $\mathrm{CO} 2$. They applied the IPCC equation for emission estimation, which follows the Seiler and Crutzen's (1980) methodology. The biomass estimation was computed using average data compiled in different areas spread across the country and they consider a constant burning efficiency factor assigned to the major vegetation classes. The dramatic forest fires occurred in Chile in 2017 highlighted the need of precise emission estimations to assess their effect on the public health and warn the population at risk.

The approach presented in this study uses accurate estimations of biomass and adapted burning efficiency values for emissions quantification. Biomass values were obtained from field work performed in the fire-affected area. The burning efficiency factor was adapted using the burned severity estimation obtained from Sentinel-2 data.

\footnotetext{
* Corresponding author
} 


\section{METHODOLOGY}

\subsection{Study area}

Our study focuses on the fires that occurred in the 2016-2017 fire season located within the Region of Valparaiso, the Region Metropolitana and the Region of O'Higgins (Chile) (Fig. 1). These fires began on December 26, 2016 and ended on March 17, 2017, with a total of 96 large and intense fires burning in this area. The Chilean Government declared state of emergency on January 20 in central-southern Chile due to multiple intense forest fires burning at the same time.

The three regions have a Mediterranean-type vegetation, which are adapted to rainy and cold winters (June to August), and dry and hot summers (December to March). In the Region of Valparaiso and Region Metropolitana the most affected land cover types were shrublands and sclerophyll forest. On the other hand, in the Region of O'Higgins native vegetation mixes with tree plantations of Pinus radiata and Eucaliptus globulus. Open forests of evergreen and sclerophyll species are mainly on south exposure slopes $(0-1,000 \mathrm{~m}$ a.s.l), while Nothofagus forests (southern hemisphere beeches) are located at higher elevations (1,000-2,000 $\mathrm{m}$ a.s.1). The fire affected 78,177 ha of sclerophyll native forest, 20,780 ha of shrublands and 75,678 ha of other uses, following the current map of land use produced by CONAF

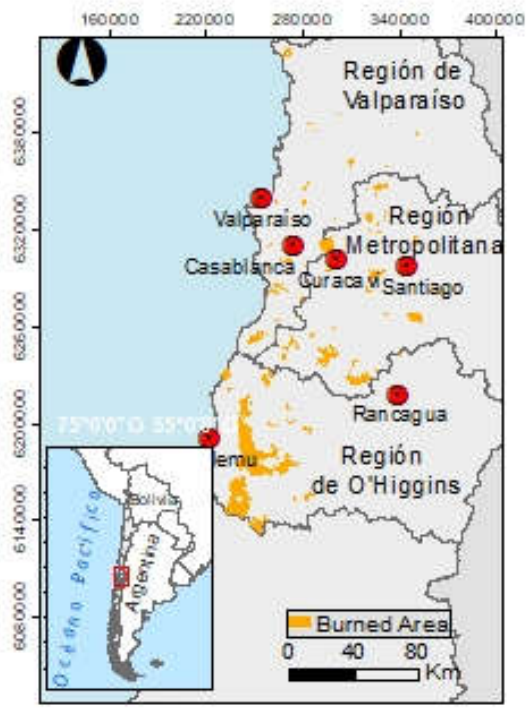

Figure 1. Location map of the three regions considered in this analysis. The burned area occurred in 2017 is represented in orange.

\subsection{Sentinel-2 data}

We use data from the Multispectral Sensor Imager (MSI) sensor on board Sentinel-2A satellite launch in June 2015 (Drusch et al. 2012). The data was downloaded from the Copernicus Open Access Hub (https://scihub.copernicus.eu/, accessed on November 15, 2019). The Sentinel-2A data has an improved spatial, spectral and temporal resolutions in comparison with Landsat images. The spatial resolution varies between 10, 20 and $60 \mathrm{~m}$ with a temporal resolution of 10 days.

The L1C product contains 13 bands ranging from the visible region of the spectrum to the red edge, Near Infrared (NIR) and
Short-Wavelength Infrared (SWIR) (Drusch et al. 2012). The L1C images were atmospherically corrected using the Sen2Cor package (Louis et al., 2016) considering a $20 \mathrm{~m}$ spatial resolution for all optical bands. To cover the entire area we selected 12 images, 6 pre-fire and 6 post-fire.

\subsection{Chilean vegetation cadaster}

The vegetation type classification was obtained from the Native forest cadaster of the three Regions considered in this analysis produced by the Chilean National forest Corporation (CONAF). These maps were generated using qualitative analysis based on photo interpretation and field work performed by experienced foresters (CONAF, 2013). The national forest cadaster is a very detail classification of vegetation types distinguishing between several levels of vegetation density. The classification system includes more than 30 land cover categories. Therefore, the original categories were reclassified to 10 vegetation types (Table 3 ).

\subsection{Field data}

From November 2018 to March 2019, thirty-nine circular plots of $12.5 \mathrm{~m}$ diameter $\left(490 \mathrm{~m}^{2}\right)$ (Table 1) were established in three of the biggest fires located in our study area and their surroundings. The location of the plots was determined to cover different vegetation types and burn severity levels. Inside the circular plots, we identified the species of the individual trees and shrubs in each plot. For those trees and shrubs, we measured the Diameter at Breast Height (DBH) or Diameter at base (DAT) according to their state (alive or dead). By ordering the information by tree size and species we could calculate the Number of trees per ha and estimate the amount of biomass (ton $\mathrm{ha}^{-1}$ ) and carbon (ton $\mathrm{ha}^{-1}$ ) for each species.

Table 1. Field data sampled where dasometric measures Diameter at Breast Height (DBH) or Diameter at base (DAT) and Composite Burn Index (CBI) were measure.

\begin{tabular}{|c|c|c|c|}
\hline Date & Location & Measure & $\mathrm{N}^{\circ}$ of plots \\
\hline \multirow[t]{2}{*}{$\begin{array}{l}\text { Nov 15th } \\
2018\end{array}$} & \multirow[t]{2}{*}{$\begin{array}{l}\text { Nilahue, Region } \\
\text { O'Higgins }\end{array}$} & $\begin{array}{l}\text { Dasometric } \\
\text { (DBH/DAT) } \\
- \text { CBI }\end{array}$ & 5 \\
\hline & & $\mathrm{CBI}$ & 4 \\
\hline \multirow{3}{*}{$\begin{array}{c}\text { Jan 1st to } \\
\text { Feb 14th } \\
2019\end{array}$} & \multirow{3}{*}{$\begin{array}{l}\text { Pirque, Region } \\
\text { Metropolitana }\end{array}$} & $\begin{array}{l}\text { Dasometric } \\
\text { (DBH/DAT) } \\
- \text { CBI }\end{array}$ & 5 \\
\hline & & & 11 \\
\hline & & $\begin{array}{l}\text { Dasometric } \\
\text { (DBH/DAT) }\end{array}$ & 7 \\
\hline \multirow[t]{2}{*}{ 06-03-2019 } & \multirow{2}{*}{$\begin{array}{l}\text { Curacaví, Region } \\
\text { Metropolitana- } \\
\text { Valparaiso }\end{array}$} & $\begin{array}{l}\text { Dasometric } \\
\text { (DBH/DAT) } \\
- \text { CBI }\end{array}$ & 4 \\
\hline & & CBI & 3 \\
\hline
\end{tabular}

\subsection{Biomass calculation}

Using the allometric equations in Table 2 we computed total biomass $(\mathrm{kg})$ and the carbon content $(\mathrm{kg})$ for the species identified in the study area and then added to account for the biomass contain in a plot. An expansion factor of 0.5 was used for the carbon estimation of some species (IPCC 1996). The biomass values computed were then assigned to the land cover type where the plot was located. In the case when there were 
several plots in one land cover type, we calculated the average of the values.

Table 2. Allometric equations use for the biomass calculation of the tree species observed in the study area. Where PS: Dry mass $(\mathrm{kg})$, DAP: Diameter at breast heigh $(\mathrm{cm})$, DAM: Diameter at 1 $\mathrm{m}(\mathrm{cm})$, DAT: Diameter at $0,3 \mathrm{~m}(\mathrm{~cm})$, d: Basal diameter $(\mathrm{mm})$, CT: Total carbon $(\mathrm{kg})$, and $f_{e}$ : Expansion factor.

\begin{tabular}{|c|c|c|c|}
\hline \multirow[b]{2}{*}{ Forest species } & \multicolumn{2}{|c|}{ Allometric equations } & \multirow[b]{2}{*}{ Ref. } \\
\hline & Biomass & Carbon & \\
\hline Acacia caven & $\mathrm{PS}=\mathrm{CT} * f_{e}^{-1}$ & $\begin{array}{l}\mathrm{CT}=0.0871 \\
* \mathrm{DAP} 2.1416\end{array}$ & $\begin{array}{l}\text { (Cruz et } \\
\text { al., 2015) }\end{array}$ \\
\hline $\begin{array}{l}\text { Quillaja } \\
\text { saponaria }\end{array}$ & $\mathrm{PS}=\mathrm{CT} * f_{e}^{-1}$ & $\begin{array}{l}\mathrm{CT}=0.0736 \\
* \mathrm{DAP}\end{array}$ & $\begin{array}{l}\text { (Cruz et } \\
\text { al., 2015) }\end{array}$ \\
\hline Lithrea caustica & $\mathrm{PS}=\mathrm{CT} * f_{e}^{-1}$ & $\begin{array}{l}\mathrm{CT}=0.9638 \\
* \mathrm{DAP} \\
2.0912\end{array}$ & $\begin{array}{l}\text { (Cruz et } \\
\text { al., 2015) }\end{array}$ \\
\hline $\begin{array}{l}\text { Cryptocaria } \\
\text { alba }\end{array}$ & $\mathrm{PS}=\mathrm{CT} * f_{e}^{-1}$ & $\begin{array}{l}\mathrm{CT}=0.0675 \\
* \mathrm{DAP} 2.352\end{array}$ & $\begin{array}{l}\text { (Cruz et } \\
\text { al., 2015) }\end{array}$ \\
\hline Trevoa trinervis & $\begin{array}{l}\mathrm{PS}=(1.5896 * \\
\left.(\mathrm{DAP} * 10)^{1.8369}\right) \\
/ 1000\end{array}$ & $\mathrm{CT}=\mathrm{PS} * f_{e}$ & $\begin{array}{l}\text { (Orrego } \\
\text { M., 2014) }\end{array}$ \\
\hline $\begin{array}{l}\text { kageneckia } \\
\text { oblonga }\end{array}$ & $\begin{array}{l}\mathrm{PS}=(0.3336 * \\
\left.(\mathrm{DAP} * 10)^{2.3592}\right) \\
/ 1000\end{array}$ & $\mathrm{CT}=\mathrm{PS} * f_{e}$ & $\begin{array}{l}\text { (Orrego } \\
\text { M., 2014) }\end{array}$ \\
\hline $\begin{array}{l}\text { Colliguaja } \\
\text { odorifera }\end{array}$ & $\begin{array}{l}\mathrm{PS}=(0.3336 * \\
\left.(\mathrm{DAP} * 10)^{2.3592}\right) \\
/ 1000\end{array}$ & $\mathrm{CT}=\mathrm{PS} * f_{e}$ & $\begin{array}{l}\text { (Orrego } \\
\text { M., 2014) }\end{array}$ \\
\hline $\begin{array}{l}\text { Escallonia } \\
\text { pulverulenta }\end{array}$ & $\begin{array}{l}\mathrm{PS}=(0.3336 * \\
\left.(\mathrm{DAP} * 10)^{2.3592}\right) \\
/ 1000\end{array}$ & $\mathrm{CT}=\mathrm{PS} * f_{e}$ & $\begin{array}{l}\text { (Orrego } \\
\text { M., 2014) }\end{array}$ \\
\hline $\begin{array}{l}\text { Eucaliptus } \\
\text { globulus }\end{array}$ & $\begin{array}{l}\mathrm{PS}=\mathrm{e}^{(2.3177+} \\
(0.1303 * \mathrm{DAP}))\end{array}$ & $\mathrm{CT}=\mathrm{PS} * f_{e}$ & $\begin{array}{l}\text { (Gayoso, } \\
\text { J., 2008) }\end{array}$ \\
\hline Pinus radiata & $\begin{array}{l}\mathrm{PS}=(-5.0506+ \\
0.8173 * \mathrm{DAP})^{2}\end{array}$ & $\mathrm{CT}=\mathrm{PS} * f_{e}$ & $\begin{array}{l}\text { (CONAF, } \\
\text { 2013) }\end{array}$ \\
\hline $\begin{array}{l}\text { Maytenus } \\
\text { boaria }(M b)\end{array}$ & $\mathrm{PS}=\mathrm{CT} * f_{e}^{-1}$ & $\begin{array}{l}\mathrm{CT}=0.152 * \\
\mathrm{DAP} 2.17\end{array}$ & $\begin{array}{l}\text { (Cruz et } \\
\text { al., 2015) }\end{array}$ \\
\hline $\begin{array}{l}\text { Nothofagus } \\
\text { glauca }\end{array}$ & $\begin{array}{l}\text { PS }=e^{((-2.86+1.81 *} \\
\text { Ln DAP })+(-2.76+1.20 * \\
\text { Ln DAP })+(-5.14+2.92 * \\
\text { Ln DAP })+(-2.64+2.39 * \\
\text { Ln DAP }))\end{array}$ & $\mathrm{CT}=\mathrm{PS} * f_{e}$ & $\begin{array}{l}\text { (CONAF, } \\
2013)\end{array}$ \\
\hline $\begin{array}{l}\text { Nothofagus } \\
\text { oblicua }\end{array}$ & $\begin{array}{l}\mathrm{PS}=\mathrm{e}^{(-2.10779+} \\
2.3896 * \text { Ln DAP })\end{array}$ & $\mathrm{CT}=\mathrm{PS} * f_{e}$ & $\begin{array}{l}\text { (CONAF, } \\
2013)\end{array}$ \\
\hline
\end{tabular}

\subsection{Burning efficiency factors}

The burning efficiency factor was adapted to the burn severity conditions as we assume that the spatial variability in the percentage of biomass consumed is related to the damage produced by the fire. Then, the burning efficiency factor will be higher at higher burn severity values.

We used the dNBR index (difference Normalized Burn Ratio, Key and Benson, 2003), which has been applied profusely in the literature to assess the burn severity of forest fires in different ecosystems [11,12]. We classified the Sentinel2 based dNBR into four categories of burn severity: low, moderate, moderate high and high. Using the values of CBI measured on the field we adapted the thresholds to classify the
dNBR into the four severity levels plus the unburned class. Then, we assigned an adapted value of combustion efficiency to each of the severity levels by vegetation type by assimilating the damage conditions observed to the value of biomass combusted. Consequently, the combustion efficiency factor values vary from 0.1 in low severity areas of tree cover to 0.98 in high severity areas of grasslands.

\subsection{Emissions estimation}

We applied the bottom-up method to estimate biomass burning emissions occurred in this region (IPCC 1996; Seiler y Crutzen 1980):

$$
\mathrm{L}_{\text {fire }}=\mathrm{A} \times \mathrm{B} \times \mathrm{Cf} \times \mathrm{Gef} \times 10^{-3}
$$

Where Lfire is the amount of gas emitted from biomass burning measured in tons; A is the burned area (ha); B is the biomass available for combustion ( $t / h a)$. $\mathrm{C}_{\mathrm{f}}$ is the combustion factor (non-dimensional); and $\mathrm{G}_{\mathrm{ef}}$ is the emission factor $(\mathrm{g} / \mathrm{kg})$.

We used the official CONAF fire perimeters as estimation of burned area, our field measure biomass and values taken from the literature for those vegetation types that were not measured in the field (Table 4), and the burn severity adapted burning efficiency factors (Table 6).

The emission factors were selected from the literature (Table 3). The literature values were assimilated to the vegetation type closer to the original. For example, we assimilated rangelands to savannah and sclerophyll forest to Californian chaparral emission factors.

Table 3. Summary of emission factor used in this study.

\begin{tabular}{|c|c|c|c|c|c|}
\hline Veg. type & $\mathrm{CO}_{2}$ & $\mathrm{CO}$ & NOx & $\begin{array}{l}\mathbf{P M} \\
2,5\end{array}$ & Reference \\
\hline $\begin{array}{l}\text { Open } \\
\text { sclerophyll } \\
\text { native for. }\end{array}$ & 1710 & 67 & 3.26 & 11.9 & $\begin{array}{c}\text { (Akagi et al. } \\
\text { 2011) }\end{array}$ \\
\hline $\begin{array}{l}\text { Dense } \\
\text { sclerophyll } \\
\text { native for. }\end{array}$ & 1710 & 67 & 3.26 & 11.9 & $\begin{array}{c}\text { (Akagi et al. } \\
\text { 2011) }\end{array}$ \\
\hline $\begin{array}{l}\text { Mixed } \\
\text { forest }\end{array}$ & 1637 & 89 & 2.51 & 12.7 & $\begin{array}{l}\text { (Akagi et al. } \\
\text { 2011) }\end{array}$ \\
\hline $\begin{array}{l}\text { Roble- } \\
\text { Hualo } \\
\text { native for. }\end{array}$ & 1801.6 & 41.9 & 0.56 & 1.3 & $\begin{array}{l}\text { (Cereceda- } \\
\text { Balic et al. } \\
\text { 2017) }\end{array}$ \\
\hline $\begin{array}{l}\text { Open } \\
\text { shrubland }\end{array}$ & 1674 & 73.8 & 2.58 & 7.06 & $\begin{array}{l}\text { (Yokelson } \\
\text { et al. 2013) }\end{array}$ \\
\hline $\begin{array}{l}\text { Dense } \\
\text { shrubland }\end{array}$ & 1674 & 73.8 & 2.58 & 7.06 & $\begin{array}{l}\text { (Yokelson } \\
\text { et al. 2013) }\end{array}$ \\
\hline Rangeland & 1686 & 63 & 3.9 & 7.17 & $\begin{array}{l}\text { (Akagi et al. } \\
\text { 2011) }\end{array}$ \\
\hline $\begin{array}{l}\text { Pinus } \\
\text { Plantation }\end{array}$ & 1947.5 & 49.3 & 0.41 & 0.84 & $\begin{array}{l}\text { (Cereceda- } \\
\text { Balic et al. } \\
\text { 2017) }\end{array}$ \\
\hline $\begin{array}{l}\text { Eucalyptus } \\
\text { plantation }\end{array}$ & 1701.6 & 38.9 & 0.58 & 1.06 & $\begin{array}{l}\text { (Cereceda- } \\
\text { Balic et al. } \\
\text { 2017) }\end{array}$ \\
\hline Grassland & 1630 & 90 & 6.5 & 9.5 & $\begin{array}{l}\text { (Wiedinmyer } \\
\text { et al. 2006) }\end{array}$ \\
\hline
\end{tabular}




\section{RESULTS AND DISCUSION}

\subsection{Biomass estimation}

We could not find in the literature biomass values for the Chilean sclerophyll native forests. As we assimilated the emission factors of sclerophyll forest to the factor reported for chaparral, we could've used their biomass value as an approximation. However, the biomass value reported by Akagi et al. (2011) for chaparral is 28.25 ton $\mathrm{ha}^{-1}$ which is half the value of biomass for open sclerophyll forest obtained from field measures. If we were to use the value found in the literature, we would be introducing an overestimation of $\mathrm{x} 2$ in the open sclerophyll forest and of $x 12$ in the dense sclerophyll forest.

In the case of Pinus and Eucalyptus plantations, Briceño et al. (2014) reported biomass values of 103.8 ton $\mathrm{ha}^{-1}$ for Pinus plantations and 54.1 ton $\mathrm{ha}^{-1}$ for Eucalyptus plantations. The estimations are not so different in the case of Eucalyptus plantations. However, the biomass for the Pinus plantations is $20 \%$ less than our field estimated value. That is why it is essential to have an up to date estimation of biomass of the vegetation different types.

Table 4. Summary of the values of biomass calculated from and field data and obtained from literature review. * The biomass value for mixed forest was calculated as the average of dense sclerophyll forest, pinus plantation and eucalyptus plantation.

\begin{tabular}{lcc}
\hline \multicolumn{1}{c}{ Vegetation type } & $\begin{array}{c}\text { Biomass } \\
\text { (Ton ha } \mathbf{~}^{-1} \text { ) }\end{array}$ & \multicolumn{1}{c}{ Source } \\
\hline $\begin{array}{l}\text { Open sclerophyll } \\
\text { native forest }\end{array}$ & 57.76 & Field data \\
$\begin{array}{l}\text { Dense sclerophyll } \\
\text { native forest }\end{array}$ & 371.32 & Field data \\
$\begin{array}{l}\text { Mixed forest } \\
\text { Roble-Hualo native } \\
\text { forest }\end{array}$ & 184.17 & Field data * \\
$\begin{array}{l}\text { Open shrulands } \\
\text { Dense Shrulands }\end{array}$ & 102.81 & (Aedo et al. 2011) \\
$\begin{array}{l}\text { Rangelands } \\
\text { Eucalyptus }\end{array}$ & 56.00 & (Michel et al., 2005) \\
plantation & 47.13 & (Michel et al., 2005) \\
Pinus plantation & 134.06 & Field data \\
Grassland & 12.50 & (Michel et al., 2005) \\
\hline
\end{tabular}

\subsection{Burning efficiency factors}

The first step in the adaptation of the burning efficiency factors was the classification of the Sentinel-2 derived dNBR spectral index into severity levels (Table 5).

Table 5. Thresholds of dNBR to obtain burn severity levels.

\begin{tabular}{lc}
\hline \multicolumn{1}{c}{ Severity level } & dNBR Value \\
\hline Not burned & $-0.1-0.1$ \\
Low & $0.1-0.27$ \\
Moderate & $0.27-0.44$ \\
Moderate-High & $0.44-0.66$ \\
High & $>0.6$ \\
\hline
\end{tabular}

Then, the burning efficiency factors were adapted to the burn severity levels combining the data from the literature and the field measures (Table 6).

Table 6. Adapted burning efficiency factors.

\begin{tabular}{|c|c|c|c|c|c|}
\hline \multirow[b]{2}{*}{ Veg. type } & \multicolumn{4}{|c|}{ Burn severity levels } & \multirow[b]{2}{*}{ Reference } \\
\hline & Low & Mod & $\begin{array}{l}\text { Mod.- } \\
\text { High }\end{array}$ & High & \\
\hline $\begin{array}{l}\text { Open } \\
\text { sclerophyll } \\
\text { native for. }\end{array}$ & 0.2 & 0.4 & 0.6 & 0.75 & $\begin{array}{l}\text { (Wiedinmyer } \\
\text { et al. 2006) }\end{array}$ \\
\hline $\begin{array}{l}\text { Dense } \\
\text { sclerophyll } \\
\text { native for. }\end{array}$ & 0.2 & 0.35 & 0.5 & 0.7 & $\begin{array}{l}\text { (Wiedinmyer } \\
\text { et al. 2006) }\end{array}$ \\
\hline $\begin{array}{l}\text { Mixed } \\
\text { forest }\end{array}$ & 0.1 & 0.2 & 0.35 & 0.45 & $\begin{array}{l}\text { Miranda et } \\
\text { al. (2005) }\end{array}$ \\
\hline $\begin{array}{l}\text { Roble- } \\
\text { Hualo } \\
\text { native for. }\end{array}$ & 0.1 & 0.2 & 0.3 & 0.4 & $\begin{array}{l}\text { (Prasad et al. } \\
\text { 2001) }\end{array}$ \\
\hline $\begin{array}{l}\text { Open } \\
\text { shrubland }\end{array}$ & 0.25 & 0.5 & 0.7 & 0.84 & $\begin{array}{l}\text { (Miranda } \\
\text { et al. 2005) }\end{array}$ \\
\hline $\begin{array}{l}\text { Dense } \\
\text { shrubland }\end{array}$ & 0.25 & 0.5 & 0.7 & 0.84 & $\begin{array}{c}\text { (Deeming, } \\
\text { Burgan, y } \\
\text { Cohen 1977) }\end{array}$ \\
\hline Rangelands & 0.2 & 0.4 & 0.6 & 0.8 & $\begin{array}{l}\text { (Wiedinmyer } \\
\text { et al. 2006) }\end{array}$ \\
\hline $\begin{array}{l}\text { Pinus } \\
\text { Plantation }\end{array}$ & 0.1 & 0.2 & 0.4 & 0.57 & $\begin{array}{l}\text { (Deeming } \\
\text { et al. 1977) }\end{array}$ \\
\hline $\begin{array}{l}\text { Eucalyptus } \\
\text { plantation }\end{array}$ & 0.1 & 0.25 & 0.35 & 0.47 & $\begin{array}{c}\text { (Walker } \\
1981 \text { ) }\end{array}$ \\
\hline Grassland & 0.83 & 0.88 & 0.95 & 0.98 & $\begin{array}{l}\text { (Wiedinmyer } \\
\text { et al. 2006) }\end{array}$ \\
\hline
\end{tabular}

\subsection{Emissions estimation}

We calculated the emissions produced by the fires occurred in three Regions in Chile for $\mathrm{CO}_{2}, \mathrm{CO}, \mathrm{NO}_{x}$, and PM 2.5 (Table 7). We also report the emissions estimated by GFED 4s (van der Werf et al. 2017). As GFED is a global model with a spatial resolution of 0.25 degree the generalization of the variables, such as biomass values and burning efficiency factors generates an overestimation of the emissions which affects outputs of the models derived from that data. Because of that, compared with our estimations the GFED values are slightly higher than the emissions derived from our calculations.

By adapting the burning efficiency factors, our emission estimations takes into account the different levels of combustion of the biomass in a fire, which is not normally taking into account in global emission models and produce significant overestimation of the emissions (Stenzel et al. 2019).

\section{CONCLUSION}

We implemented a high-resolution emissions estimation model for Central Chile. We improved the estimations given by global models by obtaining biomass data from the affected areas and introducing burn severity adapted burning efficiency factors to account for the variability in biomass combustion levels found in forest fires.

The differing values of biomass found in the literature for Pinus and Eucalyptus plantations highlighted the need for updated information about biomass values. In addition, compared with the estimations from GFED our emissions estimations are lower 
implying that the generalization of the model and its coarse spatial resolution increase the estimated emissions.

Table 7. Estimated emissions of $\mathrm{CO}_{2}, \mathrm{CO}, \mathrm{NO}_{\mathrm{x}}$ and $\mathrm{PM} 2.5$ produced by the fires occurred in three Regions in Chile.

\begin{tabular}{|c|c|c|c|c|}
\hline \multirow{2}{*}{ Veg. type } & \multicolumn{4}{|c|}{ Emissions (Gg) } \\
\hline & $\mathrm{CO} 2$ & $\mathrm{CO}$ & NOx & PM 2.5 \\
\hline $\begin{array}{l}\text { Open } \\
\text { sclerophyll } \\
\text { native forest }\end{array}$ & $2,237.40$ & 87.66 & 4.26 & 15.57 \\
\hline $\begin{array}{l}\text { Dense } \\
\text { sclerophyll } \\
\text { native forest }\end{array}$ & $7,629.06$ & 298.91 & 14.54 & 53.09 \\
\hline Mix forest & 3.62 & 0.19 & 0.005 & 0.2 \\
\hline $\begin{array}{l}\text { Roble- Hualo } \\
\text { native forest }\end{array}$ & 12.49 & 0.29 & 0.03 & 0.09 \\
\hline Open shrulands & 232.54 & 10.25 & 0.35 & 0.98 \\
\hline $\begin{array}{l}\text { Dense } \\
\text { Shrulands }\end{array}$ & 795.71 & 29.73 & 1.84 & 3.38 \\
\hline Rangelands & 320.81 & 14.14 & 0.49 & 1.35 \\
\hline $\begin{array}{l}\text { Eucalyptus } \\
\text { plantation }\end{array}$ & 326.84 & 7.48 & 0.11 & 0.21 \\
\hline $\begin{array}{l}\text { Pinus } \\
\text { plantation }\end{array}$ & $2,053.65$ & 52.03 & 0.43 & 0.88 \\
\hline Grassland & 288.78 & 15.94 & 1.15 & 1.68 \\
\hline Total & $13,900.95$ & 516.66 & 23.20 & 77.18 \\
\hline GFEDv4s & $14,197.39$ & 587.31 & 30.99 & 64.16 \\
\hline
\end{tabular}

\section{ACKNOWLEDGEMENTS}

This study was supported by the project CONICYT/FONIS SA18I0177 funded by the Chilean Government.

\section{REFERENCES}

Aedo, Darío, Ursula Doll, Oscar Vallejos, José San Martín, Luis Soto, y Iván Urzúa. 2011: Evaluación de la sustentabilidad de intervenciones silvícolas tradicionales en el tipo forestal RobleHualo. INFOR. Santiago.

Akagi, S. K., Robert J. Yokelson, Christine Wiedinmyer, M. J. Alvarado, J. S. Reid, Thomas Karl, J. D. Crounse, y P. O. Wennberg. 2011: Emission factors for open and domestic biomass burning for use in atmospheric models. Atmospheric Chemistry and Physics, 11(9), 4039-72.

Cereceda-Balic, Francisco, Mario Toledo, Victor Vidal, Fabian Guerrero, Luis A. Diaz-Robles, Ximena Petit-Breuilh, y Magin Lapuerta. 2017: Emission factors for PM2. 5, CO, CO2, NOx, $\mathrm{SO} 2$ and particle size distributions from the combustion of wood species using a new controlled combustion chamber $3 \mathrm{CE}$. Science of the Total Environment, 584, 901-10.

CONAF, Fabian Milla, Patricio Emanuelli, Angelo Sartori, y Jaime Emanuelli. 2013: Compendio de funciones alométricas para la estimación de la biomasa de especies forestales presentes en Chile. CONAF. Santiago.

Cruz, Pablo, Alejandro Bascuñan, Juan Velozo, y Marisol Rodriguez. 2015: Funciones alométricas de contenido de carbono para quillay, peumo, espino y litre. Bosque (Valdivia), 36(3), 375-81.

Deeming, John E., Robert E. Burgan, y Jack D. Cohen. 1977: The national fire-danger rating system, 1978. Vol. 39. Intermountain Forest and Range Experiment Station, Forest Service, US.

Dobbs, Cynnamon, Dave Kendal, y Craig R. Nitschke. 2014: Multiple ecosystem services and disservices of the urban forest establishing their connections with landscape structure and sociodemographics. Ecological Indicators, 43, 44-55.

Drusch, M., U. Del Bello, S. Carlier, O. Colin, V. Fernandez, F, Gascon, B. Hoersch, C. Isola, P. Laberinti, y P. Martimort. 2012: Sentinel-2: ESA's optical high-resolution mission for GMES operational services. Remote sensing of Environment, 120, 25-36.

Gayoso, Jorge. 2008. Proyecto FONDEF D98i1076. Medición y Monitoreo de la Captura de Carbono en Ecosistemas Forestales y Promoción en el Mercado Mundial del Carbono. CONICYT, Santiago

IPCC. 1996: Climate Change 1995 Impacts, Adaptations and Mitigation of Climate Change: Sicentific-Technical Analyses. First. editado por R. T. Watson, M. C. Zinyowera, y R. H. Moss. Melbourne, Australia: Cambridge University Press.

Kaiser, JW, A. Heil, MO Andreae, A. Benedetti, N. Chubarova, L. Jones, JJ Morcrette, M. Razinger, MG Schultz, y M. Suttie. 2012: Biomass burning emissions estimated with a global fire assimilation system based on observed fire radiative power.

Miranda A.I., Borrego C., Sousa M., Valente J., Barbosa P., y Carvalho A. 2005: Model of Forest Fire Emissions to the Atmosphere. Deliverable D252 of SPREAD Project.

Myers, Norman, Russell A. Mittermeier, Cristina G. Mittermeier, Gustavo A. B. Fonseca, y Jennifer Kent. 2000: Biodiversity hotspots for conservation priorities. Nature 403(February), 853-858.

Orrego Maggiolo, Javiera del Pilar. 2014: Acumulación de biomasa aérea en Colliguaja odorifera Mol., Retanilla trinervia (Gillies et Hook.) Hook. et Arn. y Berberis actinacantha Mart. en la Reserva Nacional Roblería del Cobre de Loncha. Universidad de Chile. Santiago.

Prasad, V. Krishna, Yogesh Kant, Prabhat K. Gupta, C. Sharma, AP and Mitra, y K. V. S. Badarinath. 2001: Biomass and combustion characteristics of secondary mixed deciduous forests in Eastern Ghats of India. Atmospheric Environment, 35(18), 3085-95

Seiler, Wolfgang y Paul J. Crutzen. 1980: Estimates of gross and net fluxes of carbon between the biosphere and the atmosphere from biomass burning. Climatic change, 2(3), 207247.

Stenzel, Jeffrey E., Kristina J. Bartowitz, Melannie D. Hartman, James A. Lutz, Crystal A. Kolden, Alistair MS Smith, Beverly E. Law, Mark E. Swanson, Andrew J. Larson, y William J. Parton. 2019: Fixing a snag in carbon emissions estimates from 
wildfires. Global change biology, 1-10, doi: 10.1111/gcb.14716.

Walker, J. 1981: Fuel dynamics in Australian vegetation.

van der Werf, G. R., J. T. Randerson, L. Giglio, T. T. van Leeuwen, Y. Chen, B. M. Rogers, M. Q. Mu, M. J. E. van Marle, D. C. Morton, G. J. Collatz, R. J. Yokelson, y P. S. Kasibhatla. 2017: Global Fire Emissions Estimates during 1997-2016. Earth System Science Data, 9(2), 697-720.

Wiedinmyer, Christine, SK Akagi, Robert J. Yokelson, LK Emmons, JA Al-Saadi, JJ Orlando, y AJ Soja. 2011: The Fire INventory from NCAR (FINN): A high resolution global model to estimate the emissions from open burning. Geoscientific Model Development, 4(3), 625.

Wiedinmyer, Christine, Brad Quayle, Chris Geron, Angie Belote, Don McKenzie, Xiaoyang Zhang, Susan O'Neill, y Kristina Klos Wynne. 2006: Estimating emissions from fires in North America for air quality modeling. Atmospheric Environment, 40(19), 3419-32.

Wooster, M. J., G. Roberts, P. H. Freeborn, W. Xu, Y. Govaerts, R. Beeby, J. He, A. Lattanzio, D. Fisher, y R. Mullen. 2015: LSA SAF Meteosat FRP Products - Part 1: Algorithms, Product Contents, and Analysis. Atmospheric Chemistry and Physics, 15(22), 13217-39.

Yebra, M., X. W. Quan, D. Riano, P. R. Larraondo, Aijm van Dijk, y G. J. Cary. 2018: A Fuel Moisture Content and Flammability Monitoring Methodology for Continental Australia Based on Optical Remote Sensing. Remote Sensing of Environment, 212, 260-72.

Yokelson, Robert J., I. R. Burling, J. B. Gilman, C. Warneke, C. E. Stockwell, J. de Gouw, S. K. Akagi, S. P. Urbanski, P. Veres, y J. M. Roberts. 2013: Coupling field and laboratory measurements to estimate the emission factors of identified and unidentified trace gases for prescribed fires. Atmospheric Chemistry and Physics, 13(1), 89-116. 